\title{
WEALTH EFFECT FOR U.S. ACQUIRERS FROM FOREIGN DIRECT INVESTMENTS
}

\author{
Halil Kiymaz \\ University of Houston-Clear Lake \\ Houston, TX
}

\begin{abstract}
This study investigates the wealth effects of foreign direct investments on U.S. firms during the period of 1989-2000. Overall findings indicate that U.S. acquirers experience statistically significant wealth gains of 0.57 percent around the announcement of acquisitions. The wealth effects do vary with location of target firms and acquirers' industry affiliation. Acquisitions in Europe yield significant positive wealth gains while acquisitions in Asia/Pacific, North America, and Latin/Central America regions yield negative wealth gains. The highest wealth gains to U.S. acquirers occur when they acquire targets in France followed by acquisitions in the U.K. Canadian acquisitions, on the other hand, yield negative significant wealth gains. The highest wealth gains are also observed in the services industry followed by acquisitions in the manufacturing and food industries. Acquisitions in mining/extraction, paper products, and communications sectors, on the other hand, yield statistically significant negative wealth gains to acquirers.
\end{abstract}

\section{Introduction}

The U.S. foreign direct investment (FDI) has increased to $\$ 66$ billion in 2000 from $\$ 33$ billion in 1994. Europe and Latin America are the largest recipients of the U.S. foreign investments. There are studies (i.e. Zhang, 2001; and Ramirez, 2002) investigating the determinants of foreign direct investment at the macro level by using real GDP, the real exchange rate, and political factors. Foreign direct investment in the form of mergers and acquisitions (M\&As) constitutes an important part of foreign direct investment. Given the growth in FDI flows to foreign countries over the years, one would expect to observe certain benefits accruing to firms involved in acquisition activities. Various studies have investigated the wealth effects to both the target and bidding firms involved in domestic acquisitions. The general conclusion for domestic acquisitions is that shareholders of target firms receive the largest gains from corporate takeovers while the evidence regarding the premium received by acquiring firms' shareholders is inconclusive (i.e. Malatesta, 1983; Dennis and McConnell, 1986; Dodd, 1980; and Asquith and Kim, 1982). 
Cross-border acquisitions can provide benefits to acquiring firms that might not be fully realized by their shareholders through cross-country portfolio diversification. Therefore, cross-border acquisitions may increase the value of a firm. These benefits arise from firms' greater ability to use their strategic advantages in international financial and product markets, which result from differences in such items as tax structures, markets for corporate control, government regulations, and technology. For example, Manzon, Sharp, and Travlos (1994) show that U.S. multinationals derive incremental benefits through foreign acquisitions by using their international financial networks to selectively repatriate dividends in a tax-beneficial manner. Heston and Rouwenhorst (1994) find that diversification across countries within an industry is a much more effective tool for risk reduction than industry diversification within a country.

Several studies have investigated the wealth gains in international acquisitions. Among them, Vasconcellos, Madura, and Kish (1990) and Connell and Conn (1993) examine the mergers between U.S. and the U.K. firms; Kang (1993) and Pettway, Sicherman, and Spiess (1993) focus on mergers between U.S. and Japanese firms. Fatemi (1984) and Doukas and Travlos (1988) probe U.S. firms engaged in foreign acquisitions. Harris and Ravenscraft (1991) and Cebenoyan, Papaioannou, and Travlos (1992) investigate U.S. targets of foreign firms. Dewenter (1995) compares the wealth effects of U.S. targets (chemical and retail industries) of domestic acquirers versus those of foreign acquirers. Cakici, Hessel, and Tandon (1996) and Kiymaz and Mukherjee (2000) show that country diversification plays an important role in determining wealth gains to merger participants. An overwhelming majority of studies either focus on only two countries, or else they lump all foreign countries together and thus do not examine country and industry specific differences in wealth effects.

This study examines the wealth effects that result from acquisitions announcements for U.S. firms involved in cross-border acquisitions in four different regions and 24 countries during the period of 1989-2000. Specifically this study investigates the following questions: 1) Do acquisitions by U.S. firms in the form of foreign direct investment benefit their shareholders? 2) Are there any differences in wealth gains to acquiring firms with respect to regional and country location of target firms? 3) Are there any differences in wealth gains to acquiring firms with respect to their industry affiliation?

Findings of this study indicate that U.S. acquirers experience statistically significant wealth gains of $0.57 \%$ around the announcement of acquisitions. The wealth effects depend on both location of target firms and acquirers' industry affiliation. While acquisitions in Europe yield positive wealth gains of 1.53\%, acquisitions in Asia/Pacific, North America, and Latin/Central America regions yield negative wealth gains of $-0.39,-1.90$, and $-0.50 \%$, respectively. The highest wealth gains to U.S. acquirers occur when they acquire targets in France $(2.68 \%)$ followed by acquisitions in the U.K. (2.09\%). Canadian acquisitions, on the other hand, yield significant negative wealth gains $(-1.90 \%)$. With 
respect to industry affiliation, the services industry experiences the highest wealth gains $(3.2 \%)$, followed by manufacturing $(2.01 \%)$ and food $(1.23 \%)$ industries. Acquisitions in mining/extraction $(-2.89 \%)$, paper products $(-2.17 \%)$, and communications $(-1.36 \%)$ sectors, on the other hand, yield statistically significant negative wealth gains to acquirers.

The remainder of the paper is organized as follows: Section two reviews the relevant literature. Section three describes data and methodology employed. Section four presents and analyzes the wealth effects for U.S. acquirers involved in foreign direct investment, and the final section concludes the paper.

\section{Literature Review}

The question of whether stockholders reward firms that increase their foreign involvement continues to be a focus of attention in finance literature. Most studies in this area have been concerned with performance of multinationals, which may be viewed as a portfolio of internationally diversified assets, relative to the performance of domestic firms. The empirical evidence is inconclusive and unable to show that multinational involvement enhances value of firm. If capital markets are segmented internationally or if it is more costly for individuals to obtain portfolio diversification directly, international corporate diversification may increase the value of firms. Adler and Dumas (1975) argue that diversification by multinational firms may provide a service to investors, which may not be available when capital markets are not fully integrated. Thus, theoretically as a form of international diversification, multinational acquisitions may be value-enhancing activities. Agmon and Lessard (1977) suggest that investors can achieve their international diversification objectives by holding multinational stocks. Brewer (1981) tests whether there is any difference between the performances of domestic and multinational firms and reports no statistical difference in the risk-adjusted performance of domestic and multinational firms. Fatemi (1984) reports no difference in the rate of return realized by the shareholders of multinational firms relative to those purely domestic firms except when multinational firms operate in competitive foreign markets. Hisey and Caves (1985) show that the choice between related and unrelated acquisitions bears little relation to the acquirer's base activity in the U.S. but it is somewhat affected by transaction costs and the firm's previous experience in the host country.

Doukas and Travlos (1988) investigate the impact of corporate multinationalism, through foreign acquisition, on the market value of the firm in an attempt to provide evidence on whether foreign direct investment is a wealthincreasing corporate decision. The empirical findings indicate that shareholders of internationally expanding domestic firms experience insignificant positive abnormal returns at the time of announcement of the acquisition. Conn and Connell (1990) analyze the effects that international mergers have on shareholders of participating firms in U.S.-U.K. mergers and show that both U.S. and U.K. acquirers experienced either positive or normal returns in the year preceding the month of first public announcement of the merger. 
Harris and Ravenscraft (1991) examine direct foreign investment by studying U.S. firms acquired during the period 1970-1987. The findings indicate that cross-border takeovers are more frequent in research and development intensive industries than are domestic acquisitions, targets of foreign buyers have significantly higher wealth gains than do targets of U.S. firms, and while cross-border effect on wealth gains is not well explained by industry and tax variables, it is positively related to the weakness of the U.S. dollar, indicating a significant role for exchange rate movements in foreign direct investment. Cebenoyan, Papaionnou, and Travlos (1992) investigate the wealth effects of the announcement of acquisition bids made by foreign bidders to U.S firms, and compare it with domestic takeovers. The results indicate that the market competition variable is the most dominant and consistent explanation of the difference in wealth gains between foreign and domestic takeovers of U.S. firms. Kang (1993) and Pettway, Sicherman, and Spiess (1993) investigate mergers between Japanese and U.S. firms and find significant wealth gains for both Japanese bidders and U.S. targets.

Cakici, Hessel, and Tandon (1996) compare wealth effects of U.S. bidders acquiring foreign firms with those of foreign bidders acquiring U.S. firms. They find significant wealth gains to both groups of bidders. Kiymaz and Mukherjee (2000) also report significant wealth gains to U.S. bidders and show that wealth effects are inversely related to the degree of economic co-movement between the two countries. Milman, D'Mello, Aybar, and Arbelaez (2001) show that many Latin American countries use acquisitions in the U.S. as an effective way of competing in the global environment. Kiymaz and Mukherjee (2001) examine the changes in risk of U.S. firms involved in cross-border acquisitions. The results show that the risk of U.S. firms declines and its level of significance varies across countries. Gleason, Mathur, and Singh (2000) examine the wealth gains from the acquisitions of foreign divested assets by U.S. firms. The results indicate that the market views these divestments as value generating activities. Ueng, Kim, and Lee (2000) provide evidence of wealth gains from international joint ventures. The findings indicate that shareholders of U.S. multinational firms benefit from such activities. These benefits are directly related to the level of ownership.

\section{Data and Methodology}

Table 1 reports the U.S. foreign direct investment during the 1994-2000 period. The amount of FDI has increased sharply from $\$ 33$ billion to $\$ 66$ billion. The rapid increase in FDI flows has been accompanied by increasing portion of these FDI being directed to developing countries. For example, Europe's share declined from $70 \%$ in 1994 to $50 \%$ in 1999 while Latin America's share increased from $15 \%$ to $25 \%$ during the same time period. The U.K. receives the most foreign direct investment by U.S. firms followed by Canada and Germany. 
Table 1

\section{US foreign direct investment abroad}

Panel A: Foreign direct investment with respect to regions/countries (Millions of dollars)

\begin{tabular}{lrrrrrrr}
\hline & $\mathbf{1 9 9 4}$ & $\mathbf{1 9 9 5}$ & $\mathbf{1 9 9 6}$ & $\mathbf{1 9 9 7}$ & $\mathbf{1 9 9 8}$ & $\mathbf{1 9 9 9}$ & $\mathbf{2 0 0 0}$ \\
\hline Europe & 22,608 & 27,073 & $\mathbf{1 4 , 6 4 1}$ & 24,220 & 38,681 & 39,044 & 44,795 \\
Germany & 2,877 & 2,539 & 479 & 1,040 & 2,414 & 1,232 & 2643 \\
France & 2,950 & 2,859 & $\mathrm{NA}$ & 1,405 & 2,594 & 952 & 966 \\
Netherlands & 3,838 & 1,238 & 1,428 & 2,939 & 4,776 & -299 & 1081 \\
UK & 3,808 & 8,312 & 5,312 & 14,617 & 24,242 & 26,740 & 25,197 \\
Others & 9,135 & 12,125 & 7,422 & 4,219 & 4,655 & 10,419 & 14,908 \\
Asia Pacific & 3,768 & 5,224 & 2,918 & 5,422 & 7,923 & 9,775 & 4,667 \\
Australia & -56 & 3,546 & 2,126 & 212 & 4,363 & 2,375 & 367 \\
Japan & 486 & 418 & $-1,325$ & 103 & 2,138 & 2,262 & 1,891 \\
Others & 3,338 & 1,260 & 2,117 & 5,107 & 1,422 & 5,138 & 2,409 \\
Latin/Central & & & & & & & \\
America & 4,974 & 5,908 & 5,565 & 8,682 & 16,506 & 20,345 & 11,394 \\
Argentina & 522 & 859 & 98 & 921 & 1,152 & 1,189 & 629 \\
Mexico & 1,678 & 1,273 & 698 & 2,398 & 2,836 & 1,212 & 1,444 \\
Brazil & 370 & $\mathrm{NA}$ & 1,934 & 2,962 & 3,944 & 4,952 & 1,945 \\
Venezuela & 16 & $\mathrm{NA}$ & $\mathrm{NA}$ & $\mathrm{NA}$ & 259 & 581 & 2,035 \\
Other & 2,388 & 3,776 & 2,835 & 2,401 & 8,315 & 12,411 & 5,341 \\
North America & 1,442 & 2,023 & 2,143 & 860 & 6,043 & 10,160 & 3,339 \\
Canada & 1,442 & 2,023 & 2,143 & 860 & 6,043 & 10,160 & 3,339 \\
\hline
\end{tabular}

Panel B: Foreign direct investment with respect to industry classifications (Millions of dollars)

\begin{tabular}{lrrrrrrr}
\hline & $\mathbf{1 9 9 4}$ & $\mathbf{1 9 9 5}$ & $\mathbf{1 9 9 6}$ & $\mathbf{1 9 9 7}$ & $\mathbf{1 9 9 8}$ & $\mathbf{1 9 9 9}$ & $\mathbf{2 0 0 0}$ \\
\hline All Industries & 33,659 & 40,485 & 27,533 & 40,792 & 72,447 & 79,183 & 66,088 \\
Petroleum & 1,108 & 591 & -796 & 4,905 & 7,319 & 5,072 & 3,926 \\
Food & 852 & 751 & 501 & 2,713 & 2,277 & 1,050 & 798 \\
Chemical & 1,635 & 12,072 & 773 & 556 & 2,105 & 2,208 & 781 \\
Machinery/ & & & & & & & \\
Equipment & 1,036 & 1,470 & 420 & $\mathrm{D}$ & 1,576 & 1.892 & 1,559 \\
Electronics & -501 & 2,620 & 529 & 899 & 1,868 & 473 & 9,908 \\
Wholesale trade & 6,727 & 574 & 2,513 & 364 & 1,846 & $-4,923$ & 1,868 \\
Financials & 10,801 & 8,317 & 9,028 & 16,561 & 25,456 & 32,035 & 19,710 \\
Services & 4,126 & 1,069 & 115 & 1,566 & 5,924 & 5,757 & 1,698 \\
Others & 7,875 & 13,021 & 14,450 & 13,228 & 24,076 & 35,619 & 25,840 \\
\hline
\end{tabular}

Source: Bureau of Economic Analysis.

The sample selection for empirical study is outlined in Table 2. The initial sample includes all foreign acquisitions of U.S. firms reported in Merger and 
Table 2

\section{Sample selection}

This table presents the sample selection and the selected characteristics of U.S. acquirers.

Panel A: Sample selection

\begin{tabular}{lc}
\hline & U.S. acquirers \\
\hline M\&As reported & 186 \\
Less: No news & 22 \\
Less: No data & $\underline{26}$ \\
Net Sample & 148 \\
\hline
\end{tabular}

Panel B: Frequency of sample by country/region

\begin{tabular}{lcc}
\hline Country and regions & \# of acquisitions & \% of acquisitions \\
\hline Europe & 90 & $60 \%$ \\
Germany & 9 & $6 \%$ \\
France & 9 & $6 \%$ \\
Netherlands & 9 & $6 \%$ \\
UK & 49 & $33 \%$ \\
Others & 14 & $9 \%$ \\
Asia/Pacific & 19 & $13 \%$ \\
Australia & 11 & $8 \%$ \\
Asia & 8 & $5 \%$ \\
Latin/Central America & 20 & $14 \%$ \\
Mexico & 7 & $5 \%$ \\
Latin America & 13 & $9 \%$ \\
North America & 19 & $13 \%$ \\
Canada & 19 & $13 \%$ \\
& 148 & $100 \%$ \\
\hline
\end{tabular}

Panel C: Frequency of sample by industry classification

\begin{tabular}{lcc}
\hline Industry classification & \# of acquisitions & \% of acquisitions \\
\hline SIC10-13 Mining/Extraction & 8 & $5 \%$ \\
SIC20-21 Food & 14 & $10 \%$ \\
SIC26-27 Paper Products/Publishing & 8 & $5 \%$ \\
SIC28-29 Chemicals/Petroleum & 17 & $12 \%$ \\
SIC32-38 Manufacturing & 35 & $24 \%$ \\
SIC48 Communications & 15 & $10 \%$ \\
SIC49 Utilities & 23 & $16 \%$ \\
SIC50 Retail/Trade & 6 & $4 \%$ \\
SIC60 Financials & 14 & $9 \%$ \\
SIC70 Services & 8 & $5 \%$ \\
Total & 148 & $100 \%$ \\
\hline
\end{tabular}


Acquisitions almanac issues during the period of 1989-2000. The following screening criteria are then applied to the initial sample. First, firms in the final sample should be traded on the NYSE or AMEX. This is to ensure that stock returns of firms can be retrieved from the Center for Research in Security Prices (CRSP) database. Second, firms with incomplete data on the CRSP are eliminated. Finally, firms with no news in the Wall Street Journal are eliminated. The net sample consists of 148 firms.

The sample includes acquisitions in Europe (France, Germany, Netherlands, the UK, Italy, Switzerland, Sweden, Ireland, Norway, Belgium, and Denmark), in Asia/Pacific (Australia, Japan, Pakistan, and Hong Kong), in Latin/Central America (Argentina, Brazil, Venezuela, Mexico, and Peru) and in North America (Canada). Panels B and C of Table 2 show selected characteristics of the acquiring firms. In terms of the acquired firm's location Europe ranks first with 90 acquisitions $(60 \%)$, followed by Latin/Central America with 20 acquisitions $(14 \%)$. In term of country, the U.K. ranks first, with 49 acquisitions (33\%) and Canada is a distant second with 19 acquisitions (13\%).

Panel $\mathrm{C}$ of Table 2 reports the frequency of sample by industry classification. Of the total 148 acquisitions, 35 (24\%) are in manufacturing (SIC32-38), 23 are in utilities (SIC49) (16\%), and 17 (12\%) are in chemicals/petroleum (SIC28-29) industries.

Standard event study methodology is used to measure the wealth effect of acquisitions announcements on acquiring firms. The following single-market model is employed in parameter estimation:

$$
R_{i, t}=\alpha_{i}+\beta_{i, t} \cdot R_{i, t}+\varepsilon_{i, t}
$$

Where:

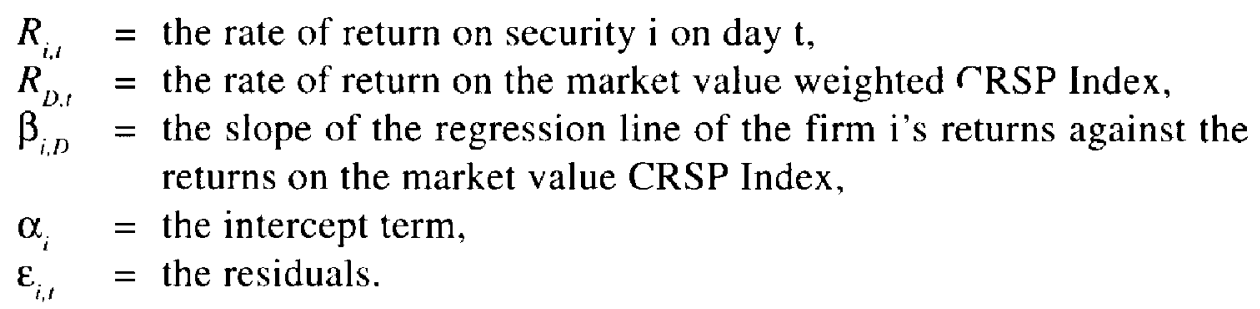

An abnormal return (wealth effect) for common stock of firm $i$ on day $t$ is defined as:

$$
A R_{i, t}=R_{i, t}-\hat{R}_{i, t}
$$

where,

$$
R_{i, r}=\alpha_{i}+\beta_{i, D} \cdot R_{D, i}
$$


in which $\alpha_{i}$ and $\beta_{i, D}$ are estimated market model parameters obtained by using the pre-estimation period $(\mathrm{t}=-316$ to $\mathrm{t}=-61)$.

The cumulative abnormal returns of firm i (CAR ) are obtained by accumulating $A R_{i, l}$ 's over a $k$-trading period running from day $d_{1}$ to day $d_{2}$ :

$$
C A R_{i}=\sum_{i=d_{i}}^{d} A R_{i, t}
$$

For a sample of $\mathrm{N}$ firms, a daily abnormal return for each day $\mathrm{t}$ is obtained:

$$
A A R_{1}=\left(\frac{l}{N}\right) \cdot \sum_{i=l}^{N} A R_{i, t}
$$

Finally, the Cumulative Average Abnormal Returns (CAR) for a sample of $\mathrm{N}$ firms across a k-day event window are calculated as follows:

$$
C A R=\left(\frac{l}{N}\right) \cdot \sum_{i=d_{i}}^{d} \sum_{i=1}^{N} A R_{i, t}
$$

The expected values of abnormal returns and average abnormal returns are zero in the absence of abnormal performance. ${ }^{2}$

\section{Empirical Results}

The impacts of foreign acquisitions announcements on U.S. acquiring firms are reported in Table 3 through Table 5. First, the behavior of abnormal returns is displayed for the entire sample of 148 acquiring firms. Panel A, Table 3, outlines average daily abnormal returns (AARs) during the 21 days surrounding the announcement of acquisitions $(t=0)$. The AARs are $0.44 \%$ on Day -1 and are statistically significant at the $1 \%$ level. This would indicate that foreign direct investments of US firms are perceived to be good news on average. The positive and statistically significant AARs on Days -4 and -2 might imply information leakage prior to the announcement. Panel B, Table 3, reports six different cumulative abnormal returns (CARs) for the acquiring firms. For $(-1,0)$ and $(-1,1)$ windows, the CARs for the entire target sample are $0.57 \%$ and $0.50 \%$ on average. Both are statistically significant. Most firms experience positive wealth gains from an acquisition announcement. CARs in the remaining windows are all positive but not statistically significant. Overall results show that markets evaluate U.S. acquiring firms involvement in foreign direct investment positively.

The sample is then grouped into sub-samples based on the geographic location of the target firms in terms of both regions and countries. Table 4 reports 
Table 3

\section{Abnormal returns surrounding foreign acquisitions announcements of US acquirers}

This table presents the abnormal return to U.S. acquirers surrounding the announcement of crossborder acquisitions. The null hypothesis is that the average abnormal returns are not statistically different from zero.

Panel A: Average daily abnormal returns (AARs)

\begin{tabular}{ccccc}
\hline \multicolumn{5}{c}{ U.S. acquirers } \\
\hline Days & AARs (\%) & t-value & Positive: Negative & Generalized Sign test \\
\hline-10 & 0.11 & 1.08 & $73: 75$ & 0.33 \\
-9 & -0.07 & -1.15 & $67: 81$ & -0.65 \\
-8 & -0.18 & -0.64 & $74: 74$ & 0.50 \\
-7 & 0.16 & 0.88 & $71: 77$ & 0.00 \\
-6 & 0.22 & 1.30 & $73: 75$ & 0.33 \\
-5 & -0.26 & $-1.60^{*}$ & $64: 84$ & -1.15 \\
-4 & 0.25 & $2.07^{* *}$ & $81: 67$ & $1.65^{*}$ \\
-3 & 0.01 & -1.16 & $67: 81$ & -0.65 \\
-2 & 0.37 & $2.04^{* *}$ & $72: 76$ & 0.17 \\
-1 & 0.13 & 0.44 & $69: 79$ & -0.33 \\
0 & 0.44 & $3.09^{* * *}$ & $80: 68$ & 1.48 \\
+1 & -0.07 & -0.22 & $64: 84$ & -1.15 \\
+2 & -0.15 & -0.57 & $59: 89$ & $-1.97^{*}$ \\
+3 & -0.17 & -1.40 & $59: 89$ & $-1.97^{*}$ \\
+4 & 0.22 & $1.60^{*}$ & $80: 68$ & 1.48 \\
+5 & 0.12 & 1.09 & $74: 74$ & 0.50 \\
+6 & 0.06 & 0.03 & $68: 80$ & -0.49 \\
+7 & -0.08 & -0.01 & $61: 87$ & $-1.64^{*}$ \\
+8 & -0.13 & -0.88 & $73: 75$ & 0.33 \\
+9 & 0.09 & 0.19 & $70: 78$ & -0.16 \\
+10 & 0.16 & 1.07 & $75: 73$ & 0.66 \\
\hline & & & &
\end{tabular}

Panel B: Cumulative abnormal returns (CARs)

\section{U.S. acquirers}

\begin{tabular}{lcccc}
\hline Windows & CARs $(\%)$ & t-value & Positive: Negative & Generalized Sign test \\
\hline$(-1,0)$ & 0.57 & $2.50^{* *}$ & $78: 70$ & 1.15 \\
$(-1,1)$ & 0.50 & $1.91^{*}$ & $75: 73$ & 0.66 \\
$(-5,5)$ & 0.90 & 1.62 & $81: 67$ & $1.65^{*}$ \\
$(-10,10)$ & 1.23 & 1.58 & $75: 73$ & 0.66 \\
$(-10,2)$ & 0.96 & 1.53 & $82: 66$ & $1.81^{+}$ \\
$(+1,6)$ & 0.02 & 0.22 & $73: 75$ & 0.33 \\
\hline
\end{tabular}

${ }^{* * * *}$ and ${ }^{*}$ indicate statistical significance at the $1 \%, 5 \%$ and $10 \%$ levels, respectively. 
both the daily average and cumulative abnormal returns for acquiring firms surrounding announcement date. In terms of regions, U.S. direct investments in Europe yield the highest positive wealth gains. In this region, AARs are $1.06 \%$ and $0.47 \%$ in Days -1 and 0 respectively. CARs for windows $(-1,0)$ and $(-10,2)$ are $1.53 \%$ and $2.48 \%$ respectively. These results are statistically significant at $1 \%$ level. Firms with acquisitions in the remaining regions (Asia/Pacific, North America, and Latin/Central America) experience negative wealth gains. For example, the daily average abnormal returns on Day -1 are $-0.69 \%,-0.88 \%$ and $-0.32 \%$ in each of the regions. Similarly, CARs for window $(-1,0)$ are $-0.39 \%$ for Asia/Pacific region, $-1.90 \%$ for North American region, and $-0.50 \%$ for Latin/ Central American region.

With respect to the locations of target firms, the wealth effects exhibit significant variations as well. The highest wealth gains are obtained in acquisitions in France and the U.K. For example, acquisitions in France yield wealth gains of $2.68 \%$ followed by wealth gains of $2.05 \%$ in U.K. by using CARs $(-1,0)$ window. Acquisitions in Canada, on the other hand, bring negative wealth gains of $-1.90 \%$ during the same event window.

Overall, the U.S. acquiring firms experience positive wealth gains in their involvement in cross-border acquisitions and the magnitude and level of significance vary from one country/region to another. The highest gains occur when U.S. firms acquire French firms followed by acquisitions of U.K. firms. Acquisitions in other regions and countries yield negative wealth gains.

Table 5 reports both average and cumulative abnormal returns for acquiring firms according to industrial classification. The findings show variations in wealth gains to acquiring firms. The highest wealth gains occur to firms in the service industry (SIC70) with an average abnormal return of $2.17 \%$ on the day of announcement. The second highest abnormal returns are observed in the manufacturing (SIC32-38) industry. The lowest AARs occur in the mining/extraction industry (SIC10-13) with $-2.65 \%$, followed by financials (SIC60-67) with $-1.04 \%$. Cumulative abnormal returns exhibit similar patterns. Six of the ten industry sub-groups experience positive wealth gains. For example, for the window $(-1,0)$, the highest wealth gains are in the service industry (SIC70) with a cumulative abnormal return of $3.22 \%$ followed by manufacturing (SIC32-38) with $2.01 \%$. The lowest CARs in $(-1,0)$ window are observed in mining/extraction (SICI0-13) industry with $-2.89 \%$ followed by paper products/publishing (SIC26-27) with $-2.17 \%$.

Overall, this study finds statistically significant wealth gains accruing to U.S. firms involved in foreign direct investment. The magnitude of gains and significance level vary for each region, country, and industrial affiliation. These findings are in line with most of the recent studies but are not supported by earlier studies. For example, while Doukas and Travlos (1988) and Conn and Connell (1990) report insignificant wealth gains to U.S. acquirers, Kang (1993), Pettway, Sicherman, and Spiess (1993), Cakici, Hessel, and Tandon (1996), and Kiymaz and Mukherjee (2000) find statistically significant positive wealth gains occurring to U.S. acquirers. This study further finds that the wealth effects do vary 


\section{Table 4}

\section{Abnormal returns to U.S. acquirers by region/country location of foreign acquisitions}

This table presents the abnormal return to U.S. firms surrounding the announcement of cross-border acquisitions based on region/country location of targets.

\begin{tabular}{|c|c|c|c|c|c|c|}
\hline & \multicolumn{3}{|c|}{$\begin{array}{c}\text { Average Abnormal Returns } \\
(A A R s)(\%)\end{array}$} & \multicolumn{3}{|c|}{$\begin{array}{l}\text { Cumulative Abnormal Returns } \\
\text { (CARs) (\%) }\end{array}$} \\
\hline & Day $(-1)$ & $\operatorname{Day}(0)$ & Day $(+1)$ & $\begin{array}{l}\text { Window } \\
(-I, 0)\end{array}$ & $\begin{array}{l}\text { Window } \\
(-10,+2)\end{array}$ & $\begin{array}{l}\text { Window } \\
(+1,+6) \\
\end{array}$ \\
\hline Europe: & $\begin{array}{l}0.47 \\
(2.37)^{*+4+}\end{array}$ & $\begin{array}{l}1.06 \\
(5.27)^{+* 4+}\end{array}$ & $\begin{array}{l}-0.02 \\
(0.49)\end{array}$ & $\begin{array}{l}1.53 \\
(5.41)^{\times * x}\end{array}$ & $\begin{array}{l}2.48 \\
(3.35)^{x * *}\end{array}$ & $\begin{array}{c}0.74 \\
(1.63)^{*}\end{array}$ \\
\hline Germany & $\begin{array}{c}-0.45 \\
(-0.43)\end{array}$ & $\begin{array}{c}0.50 \\
(1.04)\end{array}$ & $\begin{array}{l}1.53 \\
(1.99)^{* *}\end{array}$ & $\begin{array}{c}0.06 \\
(0.43)\end{array}$ & $\begin{array}{c}0.20 \\
(0.33)\end{array}$ & $\begin{array}{c}5.35 \\
(3.04)^{* * *}\end{array}$ \\
\hline France & $\begin{array}{c}0.66 \\
(1.15)\end{array}$ & $\begin{array}{l}2.02 \\
(3.51)^{* * *}\end{array}$ & $\begin{array}{c}0.52 \\
(1.40)\end{array}$ & $\begin{array}{l}2.68 \\
(3.30)^{* * *}\end{array}$ & $\begin{array}{l}5.56 \\
(3.23)^{* * *}\end{array}$ & $\begin{array}{c}1.33 \\
(1.25)\end{array}$ \\
\hline Netherlanc & $\begin{array}{l}\text { ids- } 0.91 \\
(-1.28)\end{array}$ & $\begin{array}{c}0.38 \\
(0.50)\end{array}$ & $\begin{array}{c}0.99 \\
(1.85)^{*}\end{array}$ & $\begin{array}{l}-0.53 \\
(-0.55)\end{array}$ & $\begin{array}{c}2.78 \\
(1.25)\end{array}$ & $\begin{array}{c}0.47 \\
(0.06)\end{array}$ \\
\hline UK & $\begin{array}{c}0.64 \\
(1.93)^{*}\end{array}$ & $\begin{array}{l}1.41 \\
(4.75)^{* * *}\end{array}$ & $\begin{array}{l}-0.44 \\
(-1.63)^{*}\end{array}$ & $\begin{array}{l}2.05 \\
(4.72)^{* * *}\end{array}$ & $\begin{array}{c}2.32 \\
(1.53)\end{array}$ & $\begin{array}{l}-0.34 \\
(-0.12)\end{array}$ \\
\hline Others & $\begin{array}{l}1.22 \\
(2.85)^{* * *}\end{array}$ & $\begin{array}{c}0.04 \\
(0.43)\end{array}$ & $\begin{array}{l}-0.52 \\
(0.09)\end{array}$ & $\begin{array}{l}1.26 \\
(2.32)^{* *}\end{array}$ & $\begin{array}{l}2.33 \\
(1.77)^{*}\end{array}$ & $\begin{array}{c}1.34 \\
(0.87)\end{array}$ \\
\hline Asia Pacific & $\begin{array}{l}-0.69 \\
(-2.07)^{* *}\end{array}$ & $\begin{array}{c}0.30 \\
(0.87)\end{array}$ & $\begin{array}{c}-0.31 \\
(-1.55)\end{array}$ & $\begin{array}{c}-0.39 \\
(-0.85)\end{array}$ & $\begin{array}{l}-2.86 \\
(-2.48)^{n+*-*}\end{array}$ & $\begin{array}{c}-0.17 \\
(-0.01)\end{array}$ \\
\hline Australia & $\begin{array}{l}-0.65 \\
(-1.25)\end{array}$ & $\begin{array}{c}0.34 \\
(0.58)\end{array}$ & $\begin{array}{c}-0.27 \\
(-1.00)\end{array}$ & $\begin{array}{l}-0.31 \\
(-0.47)\end{array}$ & $\begin{array}{l}-1.64 \\
(-1.34)\end{array}$ & $\begin{array}{l}-0.31 \\
(-0.10)\end{array}$ \\
\hline Others & $\begin{array}{l}-0.74 \\
(-1.73)^{*}\end{array}$ & $\begin{array}{c}0.25 \\
(0.66)\end{array}$ & $\begin{array}{l}-0.38 \\
(1.21)\end{array}$ & $\begin{array}{l}-0.50 \\
(-0.75)\end{array}$ & $\begin{array}{l}-4.54 \\
(-2.25)^{* *}\end{array}$ & $\begin{array}{l}0.01 \\
(0.10)\end{array}$ \\
\hline \multicolumn{7}{|c|}{ North America: } \\
\hline Canada & $\begin{array}{l}-0.88 \\
(-1.83)^{*}\end{array}$ & $\begin{array}{c}-1.02 \\
(-1.82)^{*}\end{array}$ & $\begin{array}{l}-0.02 \\
(0.23)\end{array}$ & $\begin{array}{l}-1.90 \\
(-2.58)^{* * * *}\end{array}$ & $\begin{array}{l}-0.60 \\
(0.09)\end{array}$ & $\begin{array}{l}-2.00 \\
(-1.28)\end{array}$ \\
\hline \multicolumn{7}{|c|}{ Latin/Central } \\
\hline America & $\begin{array}{c}0.32 \\
(-0.02)\end{array}$ & $\begin{array}{c}-0.81 \\
1(-1.86)^{*}\end{array}$ & $\begin{array}{c}-0.11 \\
(-0.37)\end{array}$ & $\begin{array}{c}-0.50 \\
(-1.33)\end{array}$ & $\begin{array}{c}-0.79 \\
(-0.61)\end{array}$ & $\begin{array}{l}-1.08 \\
(-1.60)^{*}\end{array}$ \\
\hline Mexico & $\begin{array}{c}-0.45 \\
(-0.82)\end{array}$ & $\begin{array}{c}-0.69 \\
(-1.32)\end{array}$ & $\begin{array}{c}-0.38 \\
(-0.72)\end{array}$ & $\begin{array}{l}-1.14 \\
(-1.51)\end{array}$ & $\begin{array}{l}-2.07 \\
(-1.34)\end{array}$ & $\begin{array}{c}-1.27 \\
(-1.24)\end{array}$ \\
\hline $\begin{array}{c}\text { Latin } \\
\text { America }\end{array}$ & $\begin{array}{c}0.73 \\
(0.57)\end{array}$ & $\begin{array}{c}-0.88 \\
(-1.34)\end{array}$ & $\begin{array}{c}0.03 \\
(0.07)\end{array}$ & $\begin{array}{c}-0.15 \\
(-0.54)\end{array}$ & $\begin{array}{l}-0.10 \\
(0.23)\end{array}$ & $\begin{array}{c}-0.98 \\
(-1.07)\end{array}$ \\
\hline
\end{tabular}

${ }^{* * *}$ and ${ }^{*}$ indicate statistical significance at the $1 \%, 5 \%$ and $10 \%$ levels, respectively, 
Table 5

Abnormal returns to U.S. acquirers by industrial classification

This table presents the abnormal return to U.S. firms surrounding the announcement of cross-border acquisitions based on primary standard industry classification of acquirers.

\begin{tabular}{|c|c|c|c|c|c|c|}
\hline \multirow[t]{2}{*}{ Industries } & \multicolumn{3}{|c|}{$\begin{array}{c}\text { Average Abnormal Returns } \\
(A A R s)(\%)\end{array}$} & \multicolumn{3}{|c|}{$\begin{array}{c}\text { Cumulative Abnormal Returns } \\
\text { (CARs) (\%) }\end{array}$} \\
\hline & Day (-1) & $\operatorname{Day}(0)$ & Day $(+I)$ & $\begin{array}{c}\text { Window } \\
(-1,0)\end{array}$ & $\begin{array}{l}\text { Window } \\
(-10,+2)\end{array}$ & $\begin{array}{l}\text { Window } \\
(+1,+6)\end{array}$ \\
\hline SICI0-13 & $\begin{array}{c}-0.24 \\
(-0.30)\end{array}$ & $\begin{array}{l}-2.65 \\
(-3.29)^{* * *}\end{array}$ & $\begin{array}{l}-0.04 \\
(0.11)\end{array}$ & $\begin{array}{l}-2.89 \\
(-2.54)^{* *}\end{array}$ & $\begin{array}{c}1.35 \\
(0.86)\end{array}$ & $\begin{array}{c}-4.08 \\
(-2.20)^{* *}\end{array}$ \\
\hline SIC 20-21 & $\begin{array}{c}0.01 \\
(0.13)\end{array}$ & $\begin{array}{l}1.22 \\
(2.16)^{* *}\end{array}$ & $\begin{array}{l}0.60 \\
(1.65)^{\prime}\end{array}$ & $\begin{array}{c}1.23 \\
(1.62)^{*}\end{array}$ & $\begin{array}{c}1.49 \\
(0.77)\end{array}$ & $\begin{array}{c}0.28 \\
(0.20)\end{array}$ \\
\hline SIC 26-27 & $\begin{array}{c}-1.56 \\
(-1.90)^{*}\end{array}$ & $\begin{array}{c}-0.61 \\
(-0.72)\end{array}$ & $\begin{array}{c}-0.33 \\
(-0.45)\end{array}$ & $\begin{array}{l}-2.17 \\
(-1.85)\end{array}$ & $\begin{array}{l}-4.98 \\
(-1.04)\end{array}$ & $\begin{array}{l}1.28 \\
(0.60)\end{array}$ \\
\hline SIC28-29 & $\begin{array}{c}0.66 \\
(1.62)^{*}\end{array}$ & $\begin{array}{c}0.03 \\
(0.26)\end{array}$ & $\begin{array}{c}-0.20 \\
(-0.32)\end{array}$ & $\begin{array}{c}0.69 \\
(1.33)\end{array}$ & $\begin{array}{c}0.32 \\
(0.06)\end{array}$ & $\begin{array}{c}0.79 \\
(0.56)\end{array}$ \\
\hline SIC $32-38$ & $\begin{array}{l}0.65 \\
(2.51)^{* * *}\end{array}$ & $\begin{array}{l}1.36 \\
(4.66)^{* * * *}\end{array}$ & $\begin{array}{c}-0.09 \\
(-0.08)\end{array}$ & $\begin{array}{l}2.01 \\
(5.07)^{\text {t+it }}\end{array}$ & $\begin{array}{c}1.60 \\
(1.56)\end{array}$ & $\begin{array}{c}0.98 \\
(1.12)\end{array}$ \\
\hline SIC48 & $\begin{array}{l}-0.66 \\
(-2.17)^{* * *}\end{array}$ & $\begin{array}{c}-0.70 \\
(-1.37)\end{array}$ & $\begin{array}{c}-0.50 \\
(-0.71)\end{array}$ & $\begin{array}{c}-1.36 \\
(-2.50)^{* *}\end{array}$ & $\begin{array}{c}1.41 \\
(0.32)\end{array}$ & $\begin{array}{c}-1.04 \\
(-0.52)\end{array}$ \\
\hline SIC49 & $\begin{array}{c}0.44 \\
(0.51)\end{array}$ & $\begin{array}{c}0.57 \\
(1.33)\end{array}$ & $\begin{array}{c}-0.24 \\
(-1.15)\end{array}$ & $\begin{array}{c}1.01 \\
(1.30)\end{array}$ & $\begin{array}{c}0.29 \\
(0.25)\end{array}$ & $\begin{array}{c}0.78 \\
(1.42)\end{array}$ \\
\hline SIC50 & $\begin{array}{c}0.86 \\
(0.23)\end{array}$ & $\begin{array}{c}1.05 \\
(0.39)\end{array}$ & $\begin{array}{c}1.42 \\
(1.23)\end{array}$ & $\begin{array}{c}1.91 \\
(0.44)\end{array}$ & $\begin{array}{c}5.26 \\
(0.61)\end{array}$ & $\begin{array}{c}1.15 \\
(0.07)\end{array}$ \\
\hline SIC60 & $\begin{array}{c}-1.04 \\
(-2.37)^{\text {** }}\end{array}$ & $\begin{array}{c}0.03 \\
(0.34)\end{array}$ & $\begin{array}{c}-0.35 \\
(-0.63)\end{array}$ & $\begin{array}{c}-1.01 \\
(-1.43)\end{array}$ & $\begin{array}{c}-0.20 \\
(-0.45)\end{array}$ & $\begin{array}{l}-1.84 \\
(-1.46)\end{array}$ \\
\hline SIC70 & $\begin{array}{c}1.05 \\
(1.36)\end{array}$ & $\begin{array}{l}2.17 \\
(3.12)^{* * *}\end{array}$ & $\begin{array}{c}0.07 \\
(0.54) \\
\end{array}$ & $\begin{array}{l}3.22 \\
(3.17)^{* * *}\end{array}$ & $\begin{array}{c}3.95 \\
(1.60)^{*}\end{array}$ & $\begin{array}{c}-1.15 \\
(-0.72)\end{array}$ \\
\hline
\end{tabular}

${ }^{+++}{ }^{* *}$ and ${ }^{*}$ indicate statistical significance at the $1 \%, 5 \%$ and $10 \%$ levels, respectively.

with location of target firms and acquirers' industry affiliation. While acquisitions in Europe yield positive wealth gains, acquisitions in Asia/Pacific, North America, and Latin/Central America regions yield negative wealth gains. The wealth gains are highest when acquisitions take place in France and the U.K., and lower when it takes place in Canada. Firm's industry affiliation also appears to be a source of variation in wealth gains with firms in the services industry experiencing the highest wealth gains and firms in mining/extraction industry having the lowest wealth gains.

\section{Summary and Conclusion}

The U.S. foreign direct investments have increased sharply in recent years. Foreign direct investment in the form of mergers and acquisitions (M\&As) 
constitutes an important part of foreign direct investment by U.S. firms.

This study investigates the wealth effects for U.S. firms involved in crossborder acquisitions of foreign firms during the period of 1989-2000. The sample consists of 148 acquisitions in four different regions and 24 different countries. Overall findings indicate that U.S. acquirers experience statistically significant wealth gains of $0.50 \%$ on the day of announcement. The wealth gains further differ with respect to the location of target and the industry affiliation of acquirers. Acquisitions in Europe yield the highest wealth gains of $1.53 \%$ while acquisitions in Asia/Pacific, North America, and Latin/Central America regions yield statistically significant negative wealth gains. The highest wealth gains to U.S. acquirers occur when they acquire targets in France (2.68\%) followed by acquisitions in U.K. (2.05\%). Acquisitions in Canada, on the other hand, yield negative significant wealth gains $(-1.90 \%)$. There are also differences in wealth gains with respect to industry affiliation of acquirers. The highest wealth gains are observed in services industry (3.22\%) followed by acquisitions in manufacturing $(2.01 \%)$ and food $(1.23 \%)$ industries. Acquisitions in mining/extraction $(-2.89 \%)$, paper products $(-2.17 \%)$, and communications $(-1.36 \%)$ sectors, on the other hand, yield statistically significant negative wealth gains.

Generally, this study finds that foreign direct investments by U.S. firms in the form of acquisitions are wealth-creating activities for U.S. firms. The magnitude and the level of significance of wealth gains vary from one country/region to another. Furthermore, the benefits obtained from these acquisitions are different for each sector.

\section{References}

Adler, M. \& Dumas, B. (1975), Optimal international acquisitions. Journal of Finance $20,1-19$.

Agmon, T. \& Lessard, D. R. (1977). Investor recognition of corporate international diversification. Journal of Finance 32, 1049-1055.

Asquith, P. \& Kim, E.H. (1982). The impact of mergers bids on the participating firms' security holders. Journal of Finance, 1209-1229.

Brewer, H.L. (1981). Investor benefits from corporate international diversification. Journal of Financial and Quantitative Analysis 16, 113-126.

Brown, S.J. \& Warner, J.B. ( 1985). Using daily stock returns: The case of event studies. Journal of Financial Economics 14, 3-31.

Cakici, N., Hessel, C. \& Tandon, K. (1996). Foreign acquisitions in the United States: Effect on shareholder wealth of foreign acquiring firms. Journal of Banking and Finance 20, 307-329. 
Cebenoyan, A.S., Papaioannou, G. J., \& Travlos, N.G. (1992). Foreign takeover activity in the U.S. and weatth effects for target firm shareholders. Financial Management 21, 58-68.

Conn, R.L., \& Connell, F. (1990). International mergers: Returns to U.S. and British firms. Journal of Business Finance and Accounting 17, 689-711.

Connell, F. \& Conn, R.L. (1993). A preliminary analysis of shifts in market model regression parameters in international mergers between U.S. and British firms: 1970 1980. Managerial Finance 19, 47-77.

Dennis, D.K. \& McConnell, J.J. ( 1986). Corporate mergers and security returns. Journal of Financial Economics 16, 147-187.

Dewenter, K.L. (1995). Does the market react differently to domestic and foreign takeover announcements? Evidence from the U.S. chemical and retail industries. Journal of Financial Economics 37, 421-441.

Dodd, P. (1980). Merger proposals, management discretion and stockholder wealth. Journal of Financial Economics 8, 105-137.

Doukas, J. \& Travlos, N. (1988). The effect of corporate multinationalism on shareholders' wealth: Evidence from international acquisitions. Journal of Finance 23, 1161 1178 .

Fatemi, A.M. (1984). Shareholder benefits from corporate international diversification. Journal of Finance 39 , 1325-1345.

Gleason, K., Mathur, I. \& Singh, M. (2000). Wealth effects for acquirers and divestors related to foreign divested assets. International Review of Financial Analysis 9.5 20 .

Harris, R.S. \& Ravenscraft, D. (1991). The role of acquisitions in foreign direct investment: Evidence from the U.S. stock market. Journal of Finance 46, 825-844.

Heston, S.L. \& Rouwenhorst, K.G. (1994). Does industrial structure explain the benefits of international diversification?. Journal of Financial Economics 36, 3-27.

Hisey, K.B. \& Caves, R.E. (1985). Diversification and choice of country. Journal of International Business Studies 16, 51-65.

Kang, J.K. (1993). International market for corporate control. Journal of Financial Economics 34, 345-371.

Kiymaz, H. \& Mukherjee, T.K. (2000). The impact of country diversification on wealth effects in cross-border mergers. Financial Review 35, 37-58. 
Kiymaz, H. \& Mukherjee, T.K. (2001). Parameter shifts when measuring wealth effects in cross-border mergers. Global Finance Journal 12, 249-266.

Malatesta, P.H. (1983).The wealth effect of merger activity and the objective functions of merging firms. Journal of Financial Economics 11, 155-181.

Manzon, G.B., Sharp, D.J. \& Travlos, N.G. (1994). An empirical study of the consequences of U.S. tax rules for international acquisitions by U.S. firms. Journal of Finance 49, 1893-1904.

Milman, C., D’Mello, J. Aybar, B. \& Arbelaez, H. (2001). A note using mergers and acquisitions to gain competitive advantage in the United States in the case of Latin American MNCs. International Review of Financial Analysis 10, 323-332.

Pettway, R. H., Sicherman, N.W. \& Spiess, D.K. (1993). Japanese foreign direct investment: Wealth effects purchases and sales of U.S. assets. Financial Management 22, 82-95.

Ramirez, M.D. (2002). Foreign direct investment in Mexico during the 1990s: An empirical assessment. Eastern Economic Journal 28, 409-423.

Ueng, C.J., Kim, S. \& Lee, C. (2000). The impact of firm's ownership advantages and economic status of destination country on the wealth effects of international joint ventures. International Review of Financial Analysis 9, 67-76.

Vasconcellos, G.M., Madura, J. \& Kish, R.J. (1990). An empirical investigation of factors affecting cross-border acquisitions: U.S. vs. U.K. experience, Global Finance Journal 1, 173-189.

Zhang, K.H. (2001). What attracts foreign multinational corporations to China? Contemporary Economic Policy, 336-346.

Most event studies employ a pre-estimation period to estimate the market model parameters. The length of estimation period varies between 180 and 270 days. This study uses 255 days to estimate model parameters and 60 days for event-window to analyze wealth effects.

2 The test of significance is performed by following Brown and Warner (1985) and is not illustrated here. 
Dr. Halil Kiymaz is Assistant Professor of Finance at University of Houston Clear Lake. He obtained his Ph.D. from University of New Orleans. He also holds the CFA designation. Prior joining the UHCL faculty, he has served on the faculty of Bilkent University in Turkey. His research has been published in Journal of Banking and Finance, Financial Review, Journal of Economics and Finance, Applied Financial Economics, Journal of Multinational Financial Management, Global Finance, Journal of Research in Finance, Journal of Emerging Markets, and Journal of Economics and Business Studies, among others. 